\title{
Root-rot and Stem-canker Control in Faba Bean Plants by Using Some Biofertilizers Agents
}

\author{
Safinaz A Farfour ${ }^{1,3 *}$ and Mahmoud A Al-Saman ${ }^{2,3}$ \\ ${ }^{1}$ Environmental Biotechnology Department, Sadat City University, Egypt \\ ${ }^{2}$ Industrial Biotechnology Department, Sadat City University, Egypt \\ ${ }^{3}$ Genetic Engineering and Biotechnology Research Institute (GEBRI), Sadat City University, Egypt
}

\begin{abstract}
Some biofertilizers agents i.e. Rhizobium leguminosarum var. fabae, Bacillus megaterium var., phosphaticum and Trichoderma harizianum play important roles in enhancing the plant growth and controlling several diseases $\mathrm{i}$. e. root rot and stem canker disease. In this work, under greenhouse conditions, Rhizoctonia solani caused dampingoff and death of all faba bean seedlings, however the three tested microorganisms resulted good biocontol role against the pathogenic fungus and the application of $T$. harizianum gave the best result in this trend. The treatment of $T$. harizianum and $R$. leguminosarum var. fabae to the soil infested with Rhizoctonia solani showed significant increase in leaves number of faba bean plants compared with the untreated plants or which treated plants or which treated with Bacillus megaterium var., phosphaticum after 40 days from planting. Application of $T$. harizianum and $R$. leguminosarum var. fabae gave the best plant growth while the presence of the pathogenic fungus showed significant decrease in fresh weight, dry weight and nodules number on roots of faba bean plants. Also, polyphenols and antioxidants contents in the shoots and roots were decreased in the presence of the pathogen compared with the untreated plants. Application of $R$. leguminosarum resulted significant increase in the roots and shoots total nitrogen and protein.
\end{abstract}

Keywords: Faba bean; Root- rot; Stem- canker; Polyphenol; Antioxidant Rhizobium leguminosarum; Trichoderma harizianum; Bacillus megaterium var., phosphaticum

\section{Introduction}

Since the early 1990s, induction of systemic resistance by plant growth promoting rhizobacteria (PGPR) has been investigated as a possible practical way to use induced resistance in agriculture. PGPR have been tested in the green house and field for induced systemic resistance (ISR) to fungal [1,2], pathogen in various crops such as bean, carnation, cucumber, radish, tobacco, tomato and Arabidopsis. The use of plant growth promoting rhizobacteria (PGPR) isolated from cauliflower root, Pseudomonas fluorescens SP007s as biocontrol agent in protecting various plants from several diseases caused by bacteria and fungi have been reported for multiple studies [3]. Marleny et al. [4] found that plant growth promoting rhizobacteria (PGPR) are beneficial bacteria that colonize the rhizosphere and plant roots resulting in enhancement of plant growth or protection against certain plant pathogens. One practical challenge to implementing this approach is establishing beneficial microbial communities, such as plant growth promoting rhizobacteria (PGPR) to promote soil ecosystem health that contribute to suppression of plant pathogens and other pests [5,6]. Gasoni et al. [7] showed that bacteria belonging to Pseudomonas and Bacillus genera have been used as biocontrol agents. Yehia et al. [8] proved antagonistic effect of Trichoderma virdie against Fusarium solani of faba bean. Seed coating with Trichoderma virdie increased fresh and dry weight of shoots, roots and nodules number. The population densities of fungi (including Fusarium spp.,) were low in plants obtained from treated seeds. Nelsson [9] reported that Trichoderma spp., are specific biocontrol agents against fungal pathogens (from Pythium to Rhizoctonia) according to the type of antibiotic produced. Under field conditions, Ehteshamul and Ghaffar [10] observed the antagonistic rhizobia and bradirhizobia used as seed dressing or soil drench reduced infection of Rhizoctoia solani in both leguminous and no leguminous plants. Zheng and Sinclair [11] showed that Bacillus megaterium is a potential bacterial biocontrol agent against Rhizoctonia solani. Lewis and Lumsdent [12] cleared that $T$. harizianum and T. virdie isolates reduced damping off of different plants caused by isolate R-23 of $R$. solani. Jensen et al. [13] evaluated the effect of Bacillus subtils and T. harizianum alone or in combination with Captan 400 and Vitavax 200 as biocontrol treatments against the dry bean root rot pathogens. They also recorded that seed application of both biocontrol agents increased plant biomass and decreased disease severity, under greenhouse conditions. Field experiments showed that seeds treated with $B$. subtilis reduced bean root rot and increased yield (31\%) when compared with untreated control. Maria and Joseph [14] showed that a Trichoderma harizianum strain was antagonistic; In Vitro; to Rhizoctonia solani and Verticillium dahlia and may be considered a potential biocontrol agent.

Over the last few decades, consumers demand for healthier food and governments policies focused on environmentally sustainable agricultural systems have both promoted a rapid expansion of organic farming $[15,16]$. Organic food production is characterized by the absence of synthetic compounds (herbicides, pesticides) [17]. Manach et al. [18] reported that nowadays, emphasis multi strains biofertilizer has already been tidied. Biofertilizers are biological preparations

*Corresponding author: Safinaz A. Farfour, Genetic Engineering and Biotechnology Research Institute (GEBRI), Sadat City University, Sadat City, Egypt, Tel: 00201223891971; E-mail: farfour.safinaz@yahoo.com

Received: February 05, 2014; Accepted February 19, 2014; Published February 24, 2014

Citation: Farfour SA, Al-Saman MA (2014) Root-rot and Stem-canker Control in Faba Bean Plants by Using Some Biofertilizers Agents. J Plant Pathol Microb 5: 218. doi:10.4172/2157-7471.1000218

Copyright: (c) 2014 Farfour SA, et al. This is an open-access article distributed under the terms of the Creative Commons Attribution License, which permits unrestricted use, distribution, and reproduction in any medium, provided the original author and source are credited. 
embodying, essentially, sufficient densities of potent strains of microorganisms, having a tangible beneficial role in filleting a proper rhizosphere for plant growth [19]. Organically grown cabbage, spinach, welch, union, green pepper generally had higher levels of flavonoids and antioxidants activity [20]. Dinitrios [21] showed that the health benefits of fruits and vegetables are largely due to the antioxidants and vitamins supported by the large number of phytochemicals, some with greater antioxidant properties. Also, Asami et al. [22] mentioned that phenolic and ascorbic acids are presented in higher levels in organic corn, strawberry and marine berry than in conventional. Dave et al. [23] found that there was quantitative increase in total phenol, total protein and major three fatty acids after treatment. Trichoderma also observed to introduce resistance capacity of Indian mustard plants. Some Trichoderma rhizosphere competent strains has been shown to have direct effects on plants, increasing their growth potential and nutrient uptake, fertilizer sufficiency, percentage and rate of seed germination and stimulation of plant stimulation of plant defenses against biotic and abiotic damage [24]. In cucurbits it has been found that ISR induction was correlated to the up-regulation of different pathogenesis related (PR) and defense related proteins (chitinases, glucanase, peroxidases and specific phytoalexins) and enzyme activities, especially phenylalanine ammonia lyase and synthesis of other phenols and related proteins [25].

The aim of this work is to study the effect of some biofertilizers and biocontrol agents either single or in combination applications on faba bean plants cultivated in soil infested with Rhizoctonia solani.

\section{Materials and Methods}

\section{Microorganisms tested}

Rhizobium leguminosarum var. fabae "Okkadin biofertilizer was obtained from Legume Crops Dept., Field Crops Research Institute, ARC, Giza, Egypt. Bacillus megaterium var. phosphaticum isolate was obtained from MERCIN, Fac. Of Agric., Ain Shams Univ. an Identified isolate of Tricoderma harizianum was achieved from agricultural Botany Dept., Fac. Of Agric., Minuf., Univ.,.

In order to isolate the causal organism of stem canker and root rot disease; infected faba bean plants were collected from different cultivated areas at Sadat City. Roots and stem bases of the obtained samples were separately washed by running tap water, surface sterilized by $70 \%$ Ethanol and then left to dry on sterilized filter papers. The samples were cut into small pieces, plated on PDA medium and incubated at $25^{\circ} \mathrm{C}$. Petri dishes were examined daily and hyphal tips were individually transferred to new PDA plates. Some other root samples were used for isolation of the outer microorganism "without surface sterilization". Obtained isolates were identified at the Agric. Botany Dept., Fac., of Agric., Min., Univ., Shibin El-kom, Egypt.

\section{Pot experiments}

Pots $(20 \mathrm{~cm}$ in diameter) were sterilized by immersing them in $5 \%$ Clorox for $15 \mathrm{~min}$. and then left to dry in open air. Non- sterilized sandy-loam soil of Sadat City mixed thoroughly with peat moth at the rate of 1:1 were left for a week in the open air before using in this experiment.

For Rhizobium inoculation; seeds were immersed in sugar solution as an adhesive material (prepared by dissolving $20 \mathrm{gm}$. of sugar in $100 \mathrm{ml}$ water) Treated seeds mixed thoroughly with the "Okadeen" biofertilizer and left for $30 \mathrm{~min}$. in a shadow place for drying before cultivation.
Bacillus isolate was grown on Nutrient Broth medium for $48 \mathrm{hrs}$ on a rotary shaker at $25^{\circ} \mathrm{C}$. The bacterial inoculum was applied as n soil treatment at the rate of $5 \mathrm{ml}$ bacterial suspension per plant $\left(1^{\times}\right.$ $\left.10^{8} \mathrm{cfu} / \mathrm{ml}\right)$.

However; application of fungal isolates was carried out on Barley medium at the rate of $3 \%$ of soil weight. A disc ( $4 \mathrm{~mm}$ in diameter) from the edge of 6 days old fungal culture was added to $200 \mathrm{~g}$ sterilized Malt medium ( $75 \mathrm{~g}$ malt $+25 \mathrm{~g}$ soil $+100 \mathrm{ml}$ distilled water) and incubated for 7 days at $25^{\circ} \mathrm{C}$. The inocula were mixed with the soil at weight. The pots were watered daily for 7 days before cultivation.

\section{Chemical analysis}

Total nitrogen content: The determination of total nitrogen was carried out with Micro-Kjeldahl method. [26]. Oh point five grams of dried and finely ground shoot and root sample was taken in a Kjeldahl flask. Three $\mathrm{g}$ of digestion mixture $\left(\mathrm{H}_{2} \mathrm{SO}_{4}+\mathrm{K}_{2} \mathrm{SO}_{4}\right)$ in the ratio of 1:9 was added and followed by $20 \mathrm{ml}$ of $\mathrm{H}_{2} \mathrm{SO}_{4}$. The sample was boiled in digestion apparatus for 1.5-2 hrs .until the contents became clear. The digested material was cooled and diluted up to $250 \mathrm{ml}$ in a volumetric flask by adding distilled water. An aliquot $10 \mathrm{ml}$ of it was transferred to the micro Kjeldahl distillation apparatus. It was mixed with $10 \mathrm{ml}$ of $40 \% \mathrm{NaOH}$ and distilled in a receiver containing $10 \mathrm{ml}$ of $2 \%$ boric acid solution with methyl red as indicator. The contents of the distillate were titrated against standard sulfuric acid $\left(\mathrm{N} / 10 \mathrm{H}_{2} \mathrm{SO}_{4}\right)$ to light pink color end point. From the volume of acid used, percentage of nitrogen was calculated based on ammonia liberated.

Determination of total phenolic content (TPC): The total phenolic content (TPC) was determined by the Folin Ciocalteu method [27] using spectrophotometer (UV-200-RSLW scientific). Distilled water $(3.16 \mathrm{ml})$ was mixed with the $40 \mu \mathrm{l}$ of sample, and then $200 \mu \mathrm{l}$ of Folin Ciocalteu reagent was added. After $5 \mathrm{~min}, 600 \mu \mathrm{l}$ of $20 \%$ sodium carbonate solution was added and solutions were mixed again. The solution was left at room temperature for $2 \mathrm{hrs}$.

The color intensities were measured at wave length $750 \mathrm{~nm}$. TPC expressed as grams of Gallic acid equivalents per 100g plant.

Antioxidant capacity (DPPH Assay): The free radical scavenging activity was estimated by 1, 12-picryl--diphenyl-hydrazyl (DPPH) assay using [28]. The reaction mixture contained $100 \mu \mathrm{l}$ of test extracts $(100-500 \mu \mathrm{g} / \mathrm{ml})$ and $1 \mathrm{ml}$ of methanolic solution of $0.1 \mathrm{mM} \mathrm{DPPH}$ radical. The mixture was then vigorously shaken and incubated at $37^{\circ} \mathrm{C}$ for $30 \mathrm{~min}$. The absorbance was measured at $517 \mathrm{~nm}$ using ascorbic acid $(100-500 \mu \mathrm{g} / \mathrm{ml})$ as positive control. Lower absorbance of the reaction mixture indicated higher free radical scavenging activity which was calculated using the following equation: DPPH scavenging effect (\%) $=100 \times($ Ao- A 1$) /($ Ao $)$

Where: Ao is the absorbance of the control reaction and A1 is the absorbance of reaction mixture containing DPPH and extract at 517 nm.

The antioxidant activity of the extract was expressed as IC50 value which is defined as the concentration $(\mu \mathrm{g} / \mathrm{ml})$ of extract that inhibits the formation of DPPH radicals by $50 \%$. This was obtained from linear regression analysis.

\section{Statistical analysis}

Data were statistically analyzed by analysis of variance (ANOVA) using the Statistical Analysis System [29]. Means were separated by 
Duncan's Multiple Range Test or by Fisher's Protected Least Significant Differences (LSD) at $\mathrm{P} \leq 0.05$ level.

\section{Results and Discussion}

Under green house and artificial inoculation condition; results present in Table 1 clear that Rhizoctonia solani caused emergence damping off of all seeds of each faba bean cultivar. However; the untreated control pots resulted $90 \%$ emerged and survived plants. These results clear that Giza 3 Mohassan faba bean cultivar are highly susceptible to R. solani.

Application of the tested rhizosphere microorganisms to the potted soil infested with $R$. solani showed good control to the pathogen. The best was achieved with Tricoderma harizianum where all the seeds germinated and gave $100 \%$ plant survival. Bacillus megaterium resulted $70 \%$ germination and $92.9 \%$ of them plant survival. Rhizobium leguminosarum showed the least antagonistic effect to $R$. solani where $65 \%$ of the seeds emerged and $69.2 \%$ of them survived. The same results were achieved when the tested three microorganisms together were applied to R. solani infested soil.

Application of the beneficial tested microorganisms gave good results in controlling $R$. solani. This could be due to their antagonistic effect as reported by Gasoni et al. [7], Nelsson [9], Ehteshamul-Shaque and Ghaffar [10], Zheng and Sinclair [11], Lewis and Lumsent [12], Jensen et al. [13] and Santamarina and Joseph [14]. These results also were reported by Chen et al. [1], Liu et al. [30] and Pietrse et al. [31] who showed that (PGPR) has been investigate as a possible practical way to use induced resistance to fungal pathogens in various crops. However Nelsson et al. [9] reported that Tricoderma spp., are specific biocontrol agents against Rhizoctonia solani.

Results shown in Table 2 indicate that there was no significant variation between the average number of leaves formed on faba bean plants up to 30 days of sowing in response to different biocontrol agents application. However, Tricoderma harizianum caused significant increase of leaves number as compared with Bacillus faba megaterium
35 days after seeding. The result was noticed for T. harizianum and Rhizobium leguminosarum 40 days after planting, where they result significantly more number of leaves than control and/or Bacillus megaterium treatment.

The same table also showed that faba bean plant height has been affected by soil infestation with Rhizoctonia solani, even in the presence of the significant higher plants. These results have been shown as early as 20 days and stayed up to 40 days of sowing. Generally, application of either Tricoderma harizianum or Rhizobium leguminosarum to the soil infected with $R$. solani showed the best plant growth. While application of Bacillus megaterium and/ or the three biocontrol agents resulted the worst results of plant height.

Results in Table 3 clear that flowers number of faba bean plants didn't affect by various beneficial biocontrol agents. There were no significant differences between the averages numbers of flowers emerge on the plants of various treatments up to 45 days after seeding. It is of interesting to notice that individual treatment with Rhizoctonia solani resulted complete pre-emergence damping-off. The same table showed that average number of nodules significantly decreased in response to the soil infested with $R$. solani even in the presence of biocontrol agent(s). This was noticed in comparison with the non-infested control soil. However, number of Rhizobium leguminosarum nodules was the worst when the three microorganisms were applied to the soil infested with $R$. solani. This could be due to the antagonistic effect(s) of the tested microorganisms to R. solani as mentioned before. On the other hand, the best number of nodules was achieved when Bacillus megaterium applied to the infested soil.

Results in Table 4 indicate that the average total length of faba bean plants severely affected with soil infestation with Rhizoctonia solani. Control plants, sown in sterilized soil, gave the best plant length $(58.0 \mathrm{~cm})$ after 45 days from seeding. Complete death was obtained when Giza 3 Mohassan faba bean cv. was seeded in R. solani infested pots. Significant reduction of total plant length was noticed in all treatments contained $R$. solani an one or all of the beneficial soil

\begin{tabular}{|c|c|c|c|c|}
\hline \multirow[t]{2}{*}{ Treatments } & \multicolumn{2}{|c|}{ Germinated seeds } & \multicolumn{2}{|c|}{ Survived plants } \\
\hline & Number & $\%$ & Number of plants & $\%$ \\
\hline Rhizoctonia solani+Rhizobium leguminosarum & 13 & 65 & 9 & 69.2 \\
\hline Rhizoctonia solani+Bacillus megaterium & 14 & 70 & 13 & 92.8 \\
\hline Rhizoctonia solani+Trichodrma harzianum & 20 & 100 & 20 & 100 \\
\hline Rhizoctonia solani+Rhizobium leguminosarum+Bacillus megaterium & 13 & 65 & 9 & 69.2 \\
\hline Rhizoctonia solani & 0 & 0 & 0 & 0 \\
\hline Control & 18 & 90 & 18 & 100 \\
\hline
\end{tabular}

Table 1: Effect of some rhizospheric microorganisms on seed germination of faba bean plants; Giza 3 Mohassan cv.; (10 days) and survived plants ( 30 days) in soil infested with Rhizoctonia solani.

\begin{tabular}{|c|c|c|c|c|c|c|c|c|c|c|}
\hline \multirow{3}{*}{ Treatments } & \multicolumn{10}{|c|}{ Plant age (days) } \\
\hline & \multicolumn{5}{|c|}{ Leaves number } & \multicolumn{5}{|c|}{ Length(cm) } \\
\hline & 20 & 25 & 30 & 35 & 40 & 20 & 25 & 30 & 35 & 40 \\
\hline Rhizoctonia solani+Rhizobium leguminosarum & 3.1 & 4.1 & 5.2 & 6.5 & 7.8 & $5.5^{*}$ & 7.8 & 13.3 & 16.4 & 18.5 \\
\hline Rhizoctonia solani+Bacillus megaterium & 31 & 4.1 & 5.1 & 5.6 & 6.3 & 4.3 & 7.5 & 10.8 & 15.2 & 15.2 \\
\hline Rhizoctonia solani+Trichodrma harzianum & 3.0 & 4.0 & 5.2 & 7.0 & 7.5 & 6.2 & 8.6 & 11.6 & 16.0 & 18.7 \\
\hline Rhizoctonia solani+Rhizobium leguminosarum+Bacillus megaterium & 3.0 & 4.0 & 5.0 & 6.1 & 6.8 & 4.9 & 7.1 & 9.5 & 12.9 & 16.6 \\
\hline Rhizoctonia solani & - & - & - & - & - & $N D^{* *}$ & $N D^{* *}$ & $N D^{* *}$ & $N D^{* *}$ & $N D^{* *}$ \\
\hline Control & 3.0 & 4.0 & 5.0 & 6.1 & 6.3 & 7.4 & 10.7 & 3.7 & 18.4 & 21.8 \\
\hline L.S.D ${ }_{0.05}$ & 0.79 & 2.09 & 0.77 & 1.07 & 1.13 & 0.9 & 3.33 & 4.14 & 2.25 & 3.78 \\
\hline
\end{tabular}

${ }^{* *} \mathrm{ND}=$ Not determined due to total damping-off seedlings

Table 2: Effect of some rhizospheric microorganisms on the average number of leaves and length of faba bean plants (Giza $3 \mathrm{M} \mid \mathrm{ohassan} \mathrm{cv}$. ,) grown in soil infested with Rhizoctonia solani after 20-40 days from seeding. 
Citation: Farfour SA, Al-Saman MA (2014) Root-rot and Stem-canker Control in Faba Bean Plants by Using Some Biofertilizers Agents. J Plant Pathol Microb 5: 218. doi:10.4172/2157-7471.1000218

microorganisms except that of Tricoderma harizianum which resulted insignificant reduction (12.9\%).

Shoot system fresh weight of Giza 3 Mohassan cv. Plants was significantly less than control in response to soil infestation with Rhizoctonia solani, in most cases (Table 5). The most fresh weight reduction of shoots was achieved with application of the three microorganisms to the infested soil with R. solani $4.5 / 8.8 \%)$. However, the competitive saprophytic ability could minimized the antagonistic role of each tested biocontrol agents itself [32]. Bacillus megaterium application caused (50.5\%) reduction in fresh weight. Both mentioned treatments also resulted significant reduction in roots fresh weight (6/12.4 and 5.8/12.4\% respectively). Results shown in the same table nearly clear the same response of plants dry weight as found in fresh weight. These results are also reported by Yehia et al. [8].
Results present in Table 6 clear that application of Rhizobium leguminosarum to faba bean plants sharply increased nitrogen content in both of plant roots and shoots. This may be due to its antagonistic effects against Rhizoctonia solani. Tricoderma harizianum resulted 4.7\% more nitrogen level when compare with the untreated control plants, while Bacillus megaterium gave the same result as the control. Application of the three microorganisms to the soil gave $23.7 \%$ more total nitrogen content of the whole plant than control. The same results were obtained with the protein content of the roots an shoots of plants. R. leguminosarum gave $156.2 \%$ more protein content followed by the application of the three microorganisms which increased the protein content by $148.12 \%$ while the application with $T$. harizianum gave $29.3 \%$ and B. megaterium gave the same result as the control. These results are in agreement with Dave et al. [23].

The results above clear the aggressiveness of tested Rhizoctonia

\section{Treatments}

Rhizoctonia solani+Rhizobium leguminosarum

Rhizoctonia solani+Bacillus megaterium

Rhizoctonia solani+Trichodrma harzianum

Rhizoctonia solani+Rhizobium leguminosarum+Bacillus megaterium

Rhizoctonia solani

Control

L.S.D 0.05

Average number of Flowers

\begin{tabular}{|c|c|}
\hline 4.3 & Average number of nodules \\
\hline 4.0 & 10.1 \\
\hline 4.3 & 7.8 \\
\hline 4.5 & 10.1 \\
\hline ND $^{* *}$ & 16.5 \\
\hline 4.5 & ND* $^{*}$ \\
\hline N.S & 37.6 \\
\hline
\end{tabular}

Table 3: Effect of some rhizosphere microorganisms on the average number of flowers and nodules formed on plants of the cultivarGiza 3 Mohassan infected with Rhizoctonia solani.

\section{Treatments}

Rhizoctonia solani+Rhizobium leguminosarum

Rhizoctonia solani+Bacillus megaterium

Rhizoctonia solani+Trichodrma harzianum

Rhizoctonia solani+Rhizobium leguminosarum+Bacillus megaterium

Rhizoctonia solani

Control

L.S.D 0.05

\begin{tabular}{|c|c|c|c|}
\hline \multicolumn{5}{|c|}{ Shoots and roots length $(\mathbf{c m})^{*}$} \\
\hline Shoots & Roots & Total & Length\% \\
\hline 22.8 & 25.1 & 47.9 & -17.4 \\
\hline 18.4 & 24.0 & 42.4 & -26.0 \\
\hline 21.4 & 29.1 & 50.5 & -12.9 \\
\hline 18.9 & 25.3 & 44.2 & -23.8 \\
\hline 0 & 0 & 0 & 0 \\
\hline 25.6 & 32.4 & 58.0 & - \\
\hline 3.47 & 6.32 & 9.32 & \\
\hline
\end{tabular}

${ }^{*}$ After 50 days from seeding

Table 4: Effect of some rhizospheric microorganisms on shoots and roots length of the cultivar Giza 3 Mohassan in soil infested with Rhizoctonia solani.

\begin{tabular}{|l|}
\hline Treatments \\
\hline Rhizoctonia solani+Rhizobium leguminosarum \\
\hline Rhizoctonia solani+Bacillus megaterium \\
\hline Rhizoctonia solani+Trichodrma harzianum \\
\hline Rhizoctonia solani+Rhizobium leguminosarum+Bacillus megaterium \\
\hline Rhizoctonia solani \\
\hline Control \\
\hline L.S.D $_{0.05}$ \\
\hline
\end{tabular}

\begin{tabular}{|c|c|c|c|}
\hline \multicolumn{4}{|c|}{ Average fresh weight $(\mathbf{g m})^{\star}$} \\
\hline Shoots & Roots & Total & Fresh weight\% \\
\hline 5.1 & 7.7 & 12.8 & -39.6 \\
\hline 4.7 & 5.8 & 10.5 & -50.5 \\
\hline 5.8 & 7.9 & 13.7 & -35.4 \\
\hline 4.5 & 6.0 & 10.5 & -50.5 \\
\hline- & - & - & - \\
\hline 8.8 & 12.4 & 21.2 & - \\
\hline 3.5 & 6.0 & 3.7 & \\
\hline
\end{tabular}

\begin{tabular}{|c|c|c|c|}
\hline \multicolumn{4}{|c|}{ Average dry weight (gm)* } \\
\hline Shoots & Roots & Total & Dry weight\% \\
\hline 0.8 & 0.5 & 1.3 & -27 \\
\hline 0.4 & 0.4 & 0.8 & -55.5 \\
\hline 0.6 & 0.5 & 1.1 & -38.0 \\
\hline 0.5 & 0.4 & 0.9 & -50.0 \\
\hline 0 & 0 & 0 & 0 \\
\hline 0.9 & 0.9 & 1.8 & - \\
\hline 0.25 & 0.7 & 0.05 & \\
\hline
\end{tabular}

${ }^{*}$ After 50 days from seeding

Table 5: Effect of some rhizospheric microorganisms on the fresh and dry weight of the cultivar Giza 3 Mohassan in soil infested with Rhizoctonia solani.

\begin{tabular}{|c|c|c|c|c|c|c|c|c|}
\hline \multirow{2}{*}{ Treatments } & \multicolumn{4}{|c|}{ Total nitrogen content (mg/g dry matter) } & \multicolumn{4}{|c|}{ Protein content } \\
\hline & Shoots & Roots & Total & $\%$ & Shoots & Roots & Total & $\%$ \\
\hline Rhizoctonia solani+Rhizobium leguminosarum & 2.08 & 2.08 & 4.16 & +41 & 17.5 & 17.5 & 26.0 & +156.2 \\
\hline Rhizoctonia solani+Bacillus megaterium & 1.29 & 1.66 & 2.95 & - & 8.6 & 10.37 & 18.43 & - \\
\hline Rhizoctonia solani+Trichodrma harzianum & 1.43 & 1.66 & 3.09 & +4.7 & 8.93 & 10.37 & 19.31 & +29.37 \\
\hline Rhizoctonia solani+Rhizobium leguminosarum+Bacillus megaterium & 1.57 & 2.08 & 3.65 & +23.7 & 9.81 & 17.5 & 22.81 & +148.12 \\
\hline Rhizoctonia solani & 0 & 0 & 0 & 0 & 0 & 0 & 0 & 0 \\
\hline Control & 1.29 & 1.66 & 2.95 & - & 8.6 & 10.37 & 18.43 & - \\
\hline
\end{tabular}

Table 6: Effect of some rhizospheric microorganisms on total nitrogen and protein content of Giza 3 Mohassan cv., faba bean plant in soil infested with Rhizoctonia solani. 
Citation: Farfour SA, Al-Saman MA (2014) Root-rot and Stem-canker Control in Faba Bean Plants by Using Some Biofertilizers Agents. J Plant Pathol Microb 5: 218. doi:10.4172/2157-7471.1000218

Page 5 of 6

solani isolate and its high tolerance to the tested biocontrol agents. This pathogen caused complete pre-emergence dampping off all faba bean seedlings. It also affected the growth characters of those survive in the presence of the biocontrol agents, which has a good role in this investigations as reported by Marleny et al. [4] and Shoresh et al. [24] who showed that PGPR and Tricoderma spp., are beneficial microorganisms resulting in enhancement of plant growth against certain plant pathogens.

Figure 1 show that the application of the three microorganisms gave highest amount of poly phenolic content (153.1\%) followed by the treatment of Tricoderma harizianum (137.3\%) and Bacillus megaterium $(137.3 \%)$ in the roots of faba bean plants.

The results shown in Figure 2 illustrate that the phenolic content in the shoots are similar in the roots.

Results in Table 7 show that applicaton of Rhizobium leguminosarum

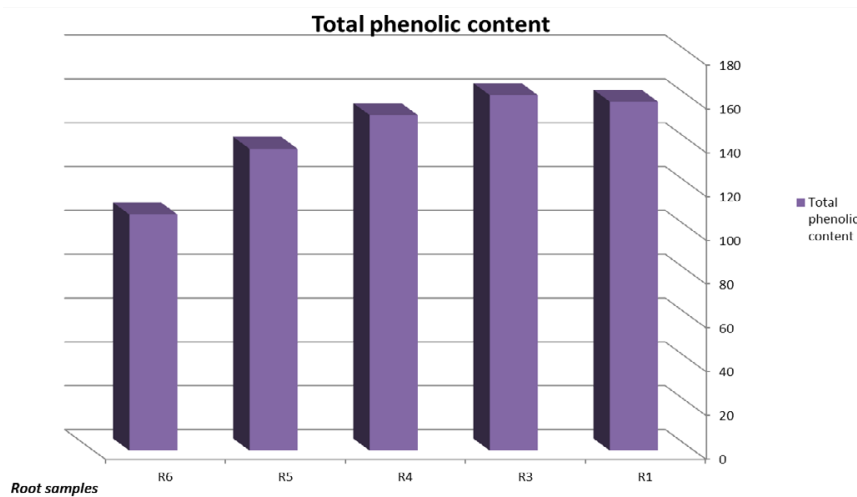

R1: Control, R3: Rhizoctonia solani + Rhizobium leguminosarum +Bacillus megaterium, R4: Rhizoctonia solani + Trichodrma harzianum, R5: Rhizoctonia solani+Bacillus megaterium, R6: Rhizoctonia solani+Rhizobium leguminosarum

Figure 1: Effect of some rhizospheric microorganisms on roots total phenolic content of Giza 3 Mohassan cv., faba bean plant in soil infested with Rhizoctonia solani.

\section{Total phenolic content}

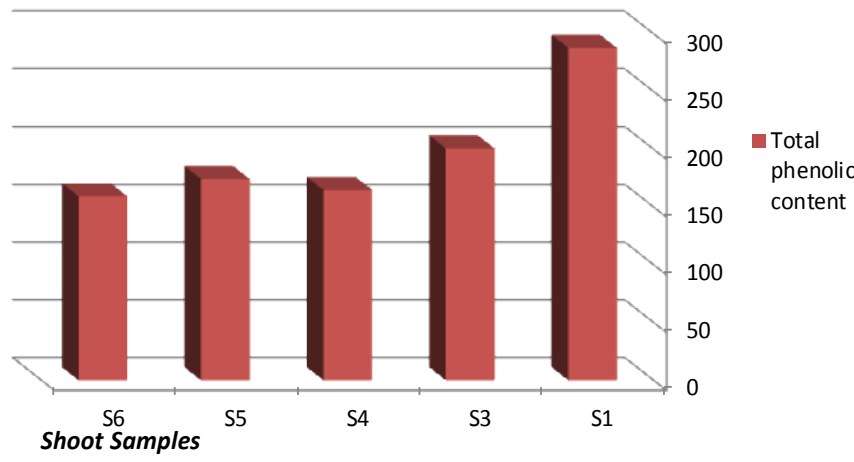

S1: Control, S3: Rhizoctonia solani + Rhizobium leguminosarum +Bacillus megaterium, S4: Rhizoctonia solani + Trichodrma harzianum, S5: Rhizoctonia solani+Bacillus megaterium, S6: Rhizoctonia solani+Rhizobium leguminosarum

Figure 2: Effect of some rhizospheric microorganisms on shoots total phenolic content of Giza 3 Mohassan cv., faba bean plant in soil infested with Rhizoctonia solani.

\begin{tabular}{|l|c|c|c|c|}
\hline \multirow{2}{*}{ Treatments } & \multicolumn{2}{|c|}{ Shoots } & \multicolumn{2}{c|}{ Roots } \\
\cline { 2 - 5 } & O.D & $\begin{array}{c}\text { Antioxidant } \\
\text { effect (\%) }\end{array}$ & O.D & $\begin{array}{c}\text { Antioxidant } \\
\text { effect (\%) }\end{array}$ \\
\hline $\begin{array}{l}\text { Rhizoctonia solani+Rhizobium } \\
\text { leguminosarum }\end{array}$ & 0.083 & 85.77 & 0.716 & 26.71 \\
\hline $\begin{array}{l}\text { Rhizoctonia solani+Bacillus } \\
\text { megaterium }\end{array}$ & 0.089 & 90.58 & 0.696 & 28.76 \\
\hline $\begin{array}{l}\text { Rhizoctonia solani+Trichodrma } \\
\text { harzianum }\end{array}$ & 0.092 & 90.58 & 0.674 & 31.01 \\
\hline $\begin{array}{l}\text { Rhizoctonia solani+Rhizobium } \\
\text { leguminosarum+Bacillus } \\
\text { megaterium }\end{array}$ & 0.092 & 90.89 & 0.654 & 33.06 \\
\hline \begin{tabular}{l} 
Rhizoctonia solani \\
\hline Control
\end{tabular} & - & - & - & \\
\hline
\end{tabular}

Stock solution conc.: $10 \mathrm{mg} / 1 \mathrm{ml}$

conc. used: $1.0 \mathrm{mg} / 0.1 \mathrm{ml}$

Table 7: Effect of some rhizospheric microorganisms on antioxidants content of Giza 3 Mohassan cv., faba bean plant in soil infested with Rhizoctonia solani.

+ Bacillus megaterium to faba bean plants gave the best levels of antioxidants in shoots (90.89\%) while application each of Tricoderma harizianum and Bacillus megaterium alone gave the same level(90.58\%) of antioxidants in shoots Rhizobium leguminosarum gave $85.7 \%$. The same results were obtained in roots (33.06, 31.01, 28.76 and $26.71 \%)$ for Rhizobium leguminosarum + Bacillus megaterium, Tricoderma harizianum, Bacillus megaterium and Rhizobium leguminosarum respectively. This result is in agreement with Ren et al. [20].

\section{Conclusion}

The three tested microorganisms has a beneficial role in controlling the root-rot disease in faba bean plants.

\section{References}

1. Chen C, Bauske EM, Musson G, Rodriguez-Ka'bana R, Kloepper JW (1995) Biological control of Fusarium wilt on cotton by use of endophytic bacteria. Biol Control 5: 83-91.

2. Park KS, Kloepper JW (2000) Activation of PR-1a promoter by rhizobacteria which induce systemic resistance in tobacco against Pseudomonas syringae pv. tabaci. Biol Control 18: 2-9.

3. Chuaboon W, Thein A, Nurapak S, Prathuangwong S (2009) Biological analysis of Pseudomonas fluorescens SP007s induced systemic resistance in sweet corn against bacterial leaf streak. In: Proceedings of the 1st Int. Conf. on Corn and Sorghum Research, Chonburi 206-215

4. Marleny BC, Nancy KB, Kathy SL, Edzard VS, Joseph WK (2008) Suppressiveness of root- knot nematodes mediated by rhizobacteria. Biological control 47: 55-59.

5. Kloepper JW, Ryu CM (2006) Bacterial endophytes as elicitors of induced systemic resistance. In: Schulz B, Boyle C, Siebern T (Eds.), Microbial Root Endophytes. Springer-Verlag, Heildelberg, 33-51.

6. Lucy M, Reed E, Glick BR (2004) Applications of free living plant growthpromoting rhizobacteria. Antonie Van Leeuwenhoek 86: 1-25.

7. Gasoni L, Cozzi J, Kobayashi K, Yossen V, Zumelzu G, et al. (1998) Suppressive effect of antagonistic agents on Rhizoctonia on lettuce and potato in Argentina field plots. In: International congress of Plant Pathology (9th-16th August, 1998, Edinburgh, Scotland), 5: 2-44.

8. Yehia AH, El-Hassan SA, Bahadi AH (1988) Biological seed treatment to contro Fusarium root rot of broad bean. Egyptian Journal of Phytopathology14: 59-66.

9. Nelsson EB (1992) Rapid germination of sporangia of Pythium species. Phytopathology 77: 1108-1112.

10. Ehteshamul-Haque S, Gaffar A (1993) Use of rhizobia in the control of root rot diseases of sunflower, okra, soybean and mung bean. J Phytopathol 138: 157-163.

11. Zheng XY, Sinclair JB (2000) The effect of traits of Bacillus megaterium on seed and root colonization root rot of soybean. Biocontrol 45: 223-243. 
Citation: Farfour SA, Al-Saman MA (2014) Root-rot and Stem-canker Control in Faba Bean Plants by Using Some Biofertilizers Agents. J Plant Pathol Microb 5: 218. doi:10.4172/2157-7471.1000218

12. Lewis JA, Lundsen RD (2001) Biocontrol of damping off greenhouse grown crops caused by Rhizoctonia solani with a formulation of Trichoderma spp. Crop Protection 22: 49-56.

13. Estevez de Jensen C, Percich JA, Graham PH (2002) Integrated management strategies of bean root rot with Bacillus subtilis and Rhizobium in Minnesota. Field Crops Researches 74: 107-115.

14. Santamarina MP, Josepha R (2006) Influence of temperature and water activity on the antagonism of Trichoderma harizianum to Verticillium and Rhizoctonia. Crop Protection 25: 110-121.

15. Hansen B, Alroeand HF, Kristean ES (2001) Approaches to assess the environmental impact of organic farming with particular regard to Denmark. Agr Eco Env 83: 11-26.

16. Van Diepenengen AD, De Vos OJ, Korthals GW, Bruggen AHC (2006) Effect of organic versus conventional management on chemical and biological parameters in agricultural soil. Agr Ecosys Environ 31: 120-135

17. Lombardi-Boccia G, Lucarini M, Lanzi S, Aguzzi A, Cappelloni M (2004) Nutrients and antioxidant molecules in yellow plums (Prunus domestica L.) from conventional and organic productions: a comparative study. J Agric Food Chem 52: 90-94

18. Manach C, Scalbert A, Morand C, Rémésy C (2004) Polyphenole rhizobia inoculants had been used in legume fields. Chem \& Eng Tech. No. 24-Life Science 1: 217-223.

19. Saber MS M (2001) Clean biotechnology for sustainable farming. Engineering in Life Science 1: 217-223.

20. Ran $H$, Bao $H$, Endo $H$, Hayashi $T$ (2001) Antioxidative and antimicrobial activities and flavonoids content of organically cultivated vegetables. Nippon, Shakuhhin Kagaku Kaishi 48: 246-252.

21. Dinitrios B (2006) Sources of natural phenolic antioxidants. Trends in Food Science \& Technology 17: 505-512.

22. Asami DK, Hong YJ, Barrett DM, Mitchell AE (2003) Comparison of the total phenolic and ascorbic acid content of freeze-dried and air-dried marionberry, strawberry, and corn grown using conventional, organic, and sustainable agricultural practices. J Agric Food Chem 51: 1237-1241.

23. Dave N, Prajapati K, Patel A, Nadini D, Bariya H (2013) Trichoderma harizianum elcits defense response in Brassica juncea plantlets. Int Res J Biological Science 2: 1-10

24. Shoresh M, Harman GE, Mastouri F (2010) Induced systemic resistance and plant responses to fungal biocontrol agents. Annu Rev Phytopathol 48: 21-43.

25. Khan J, Ooka JJ, Miller SA, Madden LV, Hoitink HAJ (2004) Systemic resistance induced by Trichoderma hamatum 382 in cucumber against Phytophthora crown rot and leaf blight. Plant Disease 88: 280-286.

26. Anonymous (1990) Official Methods of analysis of official analytical chemistry (A.O.A.C.). Pub. by the Association of Analytical Chemistry, Inc., Arlington, West Virginia, USA.

27. Singleton VL, Rossi JA (1965) Colorimetry of total phenolics with phosphomolybdic-phosphotungstic acid reagents. Am J Enol Viticul 16: 144 158.

28. Blois MS (1958) Antioxidant determinations by the use of a stable free radical. Nature 26: 1199-1200.

29. SAS Institute (1996) SAS/STAT User's Guide, Release 6.03 Edition. SAS Institute Inc., Cary, NC 27512-8000.

30. Liu L, Kloepper JW, Tuzun S (1995) Induction of systemic resistance in cucumber against Fusarium wilt by plant growth promoting rhizobacteria. Phytopathology 85: 695-698.

31. Pieterse CM, van Wees SC, Hoffland E, van Pelt JA, van Loon LC (1996) Systemic resistance in Arabidopsis induced by biocontrol bacteria is independent of salicylic acid accumulation and pathogenesis-related gene expression. Plant Cell 8: 1225-1237.

32. Ammar MM (2003) Fungi (second part): physiology, reproduction and thei relation to human and environment. El-ar El-arabia for press and distribution, Cairo 597. 